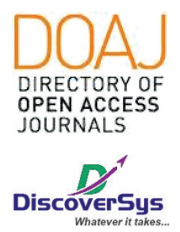

Published by DiscoverSys

\section{Hubungan antara obesitas sentral dengan kadar Hba1c pada penduduk usia 30-50 tahun di Lingkungan Batursari Desa Bitera, Gianyar}

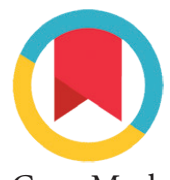

CrossMark

\author{
Putu Devita Sucitawati, ${ }^{1 *}$ DGD. Dharma Santhi, ${ }^{2}$ AA Ngurah Subawa ${ }^{2}$
}

\section{ABSTRACT}

Introduction: Central obesity is condition there is an accumulation of intraabdominal and subcutaneous fat that occurs in the abdominal area which can cause insulin resistance so that glucose is difficult to enter the cell and causes blood glucose levels to increase in Type 2 Diabetes Mellitus. Waist circumference is one indicator used for measure central obesity. This study aims to determine the relationship between central obesity and $\mathrm{HbA1}$ c levels.

Methods: This study was observational analytic with a cross sectional approach. The study population was adults aged 30-50 years in the Batursari, Bitera Village, Gianyar. Data taken included age, sex, occupation, waist circumference, BMI, HbA1c levels in 50 respondents taken by purposive sampling method. The relationship between central obesity and $\mathrm{HbA1c}$ levels was analyzed using Pearson correlation test with a significance level of 0.05 .

Result: The majority of the sample were central obesity based on waist circumference (60\%). The number of respondents with $\mathrm{HbA1c}$ level $\geq 6.5 \%$ by $30 \%$. Pearson Product Moment correlation test between central obesity and $\mathrm{HbA} 1 \mathrm{c}$ level with $\mathrm{p}=0.001$ and Pearson Correlation $r=0.456$.

Conclusion: There is a significant positive relationship between central obesity and $\mathrm{HbA} 1 \mathrm{c}$ levels

Keywords: central obesity, HbA1c levels

Cite This Article: Sucitawati, P.D., Santhi, D.G.D.D., Subawa, A.A.N. 2019. Hubungan antara obesitas sentral dengan kadar Hba1c pada penduduk usia 30-50 tahun di Lingkungan Batursari Desa Bitera, Gianyar. Intisari Sains Medis 10(3): 766-771. D0I: 10.15562/ism.v10i3.451

\title{
ABSTRAK
}

Latar Belakang: Obesitas sentral adalah suatu keadaan dimana adanya akumulasi lemak intraabdominal dan subkutan yang terjadi di daerah abdomen yang dapat menyebabkan resistensi insulin sehingga glukosa sulit untuk memasuki sel dan menyebabkan kadar glukosa darah meningkat pada penyakit Diabetes Mellitus Tipe 2. Lingkar pinggang merupakan salah satu indikator yang digunakan untuk mengukur obesitas sentral. Penelitian ini bertujuan untuk mengetahui tentang hubungan antara obesitas sentral dengan kadar HbA1c.

Metode: Penelitian ini bersifat observasional analitik dengan pendekatan cross sectional. Populasi penelitian adalah penduduk dewasa usia 30-50 tahun di Lingkungan Batursari, Desa Bitera,
Gianyar. Data yang diambil meliputi usia, jenis kelamin, pekerjaan, lingkar pinggang, IMT, kadar HbA1c pada 50 responden yang diambil dengan metode purposive sampling. Hubungan antara obesitas sentral dengan kadar HbA1c dianalisis dengan menggunakan uji korelasi Pearson dengan derajat kemaknaan 0,05.

Hasil: Hasil penelitian menunjukkan bahwa sebagian besar mengalami obesitas sentral berdasarkan lingkar pinggang (60\%). Jumlah responden dengan kadar $\mathrm{HbA1c} \geq 6,5 \%$ sebesar $30 \%$. Uji korelasi Pearson Product Moment antara obesitas sentral dengan kadar $\mathrm{HbA1}$ c dengan nilai $\mathrm{p}=0,001$ dan nilai Pearson Correlation $r=0,456$. Simpulan: Terdapat hubungan positif bermakna antara obesitas sentral dengan kadar HbA1c.
${ }^{1}$ Program Studi Pendidikan Dokter Fakultas

${ }^{2}$ Departemen Patologi Klinis Fakultas Kedokteran Universitas Udayana

*Korespondensi:

Putu Devita Sucitawati, Program

Studi Pendidikan Dokter Fakultas Kedokteran Universitas Udayana dhitasucita@gmail.com

Diterima: 19-03-2019

Disetujui: 21-11-2019

Diterbitkan: 01-12-2019
Kata kunci: obesitas sentral, kadar HbA1c.

Cite Pasal Ini: Sucitawati, P.D., Santhi, D.G.D.D., Subawa, A.A.N. 2019. Hubungan antara obesitas sentral dengan kadar Hba1c pada penduduk usia 30-50 tahun di Lingkungan Batursari Desa Bitera, Gianyar. Intisari Sains Medis 10(3): 766-771. D0I: 10.15562/ism.v10i3.451

\section{PENDAHULUAN}

Penelitian epidemiologi menunjukkan adanya kecenderungan peningkatan angka insidensi dan prevalensi Diabetes Mellitus Tipe 2 di berbagai penjuru dunia. ${ }^{1}$ Lebih dari $80 \%$ individu yang mengalami DM Tipe 2 adalah orang dewasa yang mengalami obesitas. ${ }^{2}$ Menurut World Health
Organization (WHO) (2004), berdasarkan distribusi lemak maka obesitas dapat dibedakan menjadi 2 jenis yaitu obesitas umum dan obesitas sentral. ${ }^{3}$

Metode yang digunakan untuk mengukur tingkat obesitas umum adalah dengan menggunakan Indeks Massa Tubuh (IMT). Indeks Massa Tubuh 
dapat dihitung dengan cara berat badan dalam satuan $\mathrm{kg}$ dibagi tinggi badan kuadrat dalam satuan $\mathrm{m}^{2}$ dan nilai IMT tidak dapat membedakan antara berat yang berhubungan dengan otot dan lemak. Sedangkan untuk mengukur obesitas sentral digunakan lingkar pinggang (waist circumference), rasio pinggang panggul (waist-hip ratio), rasio lingkar pinggang dengan tinggi badan (waist to-height-ratio). ${ }^{3}$ Lingkar pinggang merupakan salah satu indikator yang digunakan untuk mengukur distribusi lemak dalam tubuh. Ukuran pinggang normal pada orang Asia adalah $<90 \mathrm{~cm}$ untuk laki-laki sedangkan $<80 \mathrm{~cm}$ untuk perempuan. Apabila melebihi batas normal yaitu $\geq 90 \mathrm{~cm}$ untuk lakilaki dan $\geq 80 \mathrm{~cm}$ untuk perempuan maka berisiko untuk terkena penyakit metabolik yaitu DM Tipe $2 .^{4}$

Salah satu faktor yang mempengaruhi timbulnya kadar gula darah yang tinggi adalah obesitas, terutama yang bersifat sentral. ${ }^{5}$ Obesitas sentral adalah suatu keadaan dimana adanya akumulasi lemak intraabdominal dan subkutan yang terjadi di daerah abdomen yang dapat menyebabkan resistensi insulin (penurunan kerja insulin pada jaringan sasaran) sehingga glukosa sulit untuk memasuki sel dan menyebabkan kadar glukosa darah meningkat pada penderita $\mathrm{DM}^{6}$

Pengendalian glukosa darah pada penderita DM Tipe 2 dilihat dari dua hal yaitu glukosa darah sesaat dan glukosa darah jangka panjang. Pemantauan glukosa darah sesaat dilihat dari glukosa darah puasa dan 2 jam post prandial, sedangkan pengontrolan glukosa darah jangka panjang dapat dilakukan dengan pemeriksaan HbAlc. Pemeriksaan kadar HbAlc mencerminkan rerata pengontrolan glukosa darah dalam 2-3 bulan terakhir. ${ }^{2}$ Tingginya kadar $\mathrm{HbAlc}$ berkorelasi positif dengan terjadinya komplikasi DM, baik makro maupun mikro vaskuler. $^{7}$

Berbagai penelitian telah menunjukkan bahwa obesitas sentral berkaitan dengan kadar HbAlc yang tinggi. Masih adanya perbedaan hasil dari berbagai penelitian tersebut, tidak semua faktor obesitas sentral secara signifikan berpengaruh terhadap tingginya kadar HbAlc. Masih ada celah penelitian (research gap), maka penelitian mengenai hubungan obesitas sentral dengan tingginya kadar HbAlc masih sangat relevan untuk diteliti lebih lanjut. Berdasarkan latar belakang di atas maka peneliti tertarik untuk meneliti tentang hubungan antara obesitas sentral dengan kadar HbAlc. Adapun tujuan dilakukannya penelitian: 1)Untuk mengetahui prevalensi obesitas sentral pada penduduk usia 30-50 tahun di Lingkungan Batursari, Desa Bitera, Gianyar, 2)Untuk mengetahui kadar HbAlc pada penduduk usia 30-50 tahun di Lingkungan Batursari, Desa Bitera, Gianyar,
3)Untuk mengetahui hubungan antara obesitas sentral dengan kadar HbAlc pada penduduk usia 30-50 tahun di Lingkungan Batursari, Desa Bitera, Gianyar.

\section{METODE}

Penelitian ini adalah deskriptif observasional dengan rancangan penelitian cross sectional dimana dilaksanakan di Lingkungan Batursari, Desa Bitera Wilayah Kerja Puskesmas Gianyar II pada bulan September 2018 sampai dengan Oktober 2018. Subyek penelitian dipilih dari populasi yang memenuhi kriteria inklusi yaitu penduduk dewasa usia 30-50 tahun, bersedia mengikuti pengukuran lingkar pinggang dan pemeriksaan laboratorium HbAlc dan tinggal di Lingkungan Batursari, Desa Bitera. Serta tidak memenuhi kriteria eksklusi yaitu menderita penyakit komplikasi lain seperti stroke, gagal ginjal, memakai obat penurunan kadar lemak darah, obat hipoglikemi oral dan suntikan insulin. Teknik penentuan sampel yaitu nonprobability sampling dengan Purposive sampling. Jumlah sampel yang memenuhi kriteria inklusi sebanyak 50 orang.

Data berupa data primer dimana pengumpulan data obesitas sentral dilakukan pemeriksaan fisik dengan pengukuran lingkar pinggang dengan cara mengukur keliling perut melalui pertengahan krista iliaka (iliac crest) dengan tulang rusuk terbawah secara horizontal. Pengukuran menggunakan pita ukur atau metlin dengan tingkat ketelitian $0,1 \mathrm{~cm}$. Responden tergolong obesitas sentral berdasarkan kriteria untuk orang dewasa Asia yaitu jika lingkar pinggang responden laki-laki $\geq 90 \mathrm{~cm}$ dan perempuan $\geq 80 \mathrm{~cm} .{ }^{8}$ Selanjutnya dilakukan pengukuran IMT dengan mengukur berat badan menggunakan timbangan dengan ketelitian $0,1 \mathrm{~kg}$ dan tinggi badan menggunakan stature meter dengan ketelitian $0,1 \mathrm{~cm}$. Cut off point obesitas untuk penduduk Asia Pasifik yaitu $\geq 25,0 \mathrm{~kg} / \mathrm{m}^{2}$, berdasarkan hal ini maka di Asia Pasifik, obesitas dibagi menjadi 2 macam yaitu obesitas tingkat I dengan IMT 25,0 $29,9 \mathrm{~kg} / \mathrm{m}^{2}$ dan obesitas tingkat II dengan IMT $\geq 30,0 \mathrm{~kg} / \mathrm{m}^{2}{ }^{9}$ Kemudian dilakukan pemeriksaan kadar HbAlc dengan metode Boronate Affinity Chromatography. Diagnosis DM ditegakkan jika nilai $\mathrm{HbA} 1 \mathrm{c} \geq 6,5 \%{ }^{10}$

Uji normalitas data menggunakan uji Kolmogorov-Smirnov. Data yang berdistribusi normal selanjutnya dianalisis dengan uji korelasi Pearson Product Moment. Hasil uji ini dinyatakan dengan $\mathrm{p}$ value, pada CI 95\% sama dengan a 0,05 apabila nilai $\mathrm{p}$ value $<0,05$ dikatakan terdapat korelasi yang bermakna secara statistik atau ada hubungan antara obesitas sentral dengan kadar HbA1c. Untuk mengetahui kekuatan hubungan 
antar variabel, dilakukan uji Pearson Correlation (r). Data kemudian dianalisis dengan bantuan software IBM SPSS Statistics 20.

\section{HASIL}

Data karakteristik umum sampel penelitan meliputi usia, jenis kelamin dan pekerjaan dapat dilihat pada

\section{Tabel 1 Karakteristik Sampel}

\begin{tabular}{lcc}
\hline Karakteristik & Jumlah & (\%) \\
\hline Usia responden (tahun) & 11 & 22 \\
30-40 tahun & 39 & 78 \\
$41-50$ tahun & & \\
Jenis Kelamin & 25 & 50 \\
Laki-Laki & 25 & 50 \\
Perempuan & & \\
Pekerjaan & 4 & 8,0 \\
Swasta & 31 & 62,0 \\
Wiraswasta & 7 & 14.0 \\
PNS & 2 & 4,0 \\
Polisi & 3 & 6,0 \\
Ibu Rumah Tangga & 3 & 6,0 \\
Buruh & & \\
\hline
\end{tabular}

Tabel 2 Distribusi Variabel Penelitian

\begin{tabular}{lcccc}
\hline Variabel & Jumlah & $\%$ & Mean (min-maks) & $\begin{array}{c}\text { Standar } \\
\text { Deviasi }\end{array}$ \\
\hline $\begin{array}{l}\text { Obesitas Sentral } \\
\quad \text { Obesitas sentral }\end{array}$ & 30 & 60 & $97,90(82-105$ & 5,72 \\
$\quad \begin{array}{l}\text { Tidak obesitas sentral } \\
\text { Kadar HbA1c }\end{array}$ & 20 & 40 & $81(76-89)$ & 5,14 \\
$\quad$ Normal & 35 & 70 & $5,806(4,6-6,4)$ & 0,4576 \\
$\quad$ Meningkat & 15 & 30 & $8,453(6,7-8,9)$ & 0,6243 \\
$\begin{array}{l}\text { Indeks Massa Tubuh } \\
\text { Normal }\end{array}$ & 3 & 6 & $22,29(21,71-22,76)$ & 0,533 \\
$\quad \begin{array}{l}\text { Pre-Obese } \\
\text { Obese I }\end{array}$ & 7 & 14 & $24,55(24,14-24,97)$ & 0,348 \\
$\quad$ Obese II & 36 & 72 & $26,59(25,25-29,82)$ & 1,289 \\
& 4 & 8 & $31,86(30,04-35,20)$ & 2,316 \\
\hline
\end{tabular}

Tabel 3 Hubungan Antara Obesitas Sentral Dengan Kadar HbA1c

\begin{tabular}{|c|c|c|c|c|}
\hline \multirow[b]{2}{*}{ Obesitas Sentral $^{\mathrm{a}}$} & \multicolumn{2}{|c|}{ Kadar HbA1 $c^{b}$} & \multirow[b]{2}{*}{ P-Valaue } & \multirow[b]{2}{*}{$r$} \\
\hline & Meningkat & Normal & & \\
\hline Iya & $15(50.0 \%)$ & $15(50.0 \%)$ & \multirow{3}{*}{$0,001^{\star}$} & \multirow{3}{*}{0,456} \\
\hline Tidak & $0(0.0 \%)$ & $20(100.0 \%)$ & & \\
\hline Total & $15(30.0 \%)$ & $35(70.0 \%)$ & & \\
\hline
\end{tabular}

a $($ Kolmogorov-Smirnov $\mathrm{p}=0,222)$

${ }^{\mathrm{b}}($ Kolmogorov-Smirnov $\mathrm{p}=0,102)$

*(uji korelasi Pearson Product Moment) tabel 1.30 orang (60\%) mengalami obesitas sentral dan sebanyak 20 orang (40\%) tidak mengalami obesitas sentral. 35 orang (70\%) dalam kategori HbAlc normal dan sebanyak 15 orang (30\%) dalam kategori HbAlc meningkat. 36 orang (72\%) dalam kategori obese I, 7 orang (14\%) pre-obese, 4 orang ( $8 \%$ ) obese II dan 3 orang (6\%) dalam kategori normal (Tabel 2).

Berdasarkan tabel 2, Rerata ukuran diameter lingkar pinggang responden yang mengalami obesitas sentral sebesar $97,90 \mathrm{~cm}$, sedangkan rerata ukuran diameter lingkar pinggang responden yang tidak mengalami obesitas sentral sebesar $81 \mathrm{~cm}$. Rerata kadar HbAlc yang mengalami peningkatan adalah 8,453 \%. Rerata IMT responden yang normal adalah $22,29 \mathrm{~kg} / \mathrm{m}^{2}$, rerata IMT responden yang pre-obese adalah $24,55 \mathrm{~kg} / \mathrm{m}^{2}$, rerata IMT responden yang obese I adalah $26,95 \mathrm{~kg} / \mathrm{m}^{2}$, rerata IMT responden yang obese II adalah $31,86 \mathrm{~kg} / \mathrm{m}^{2}$.

Berdasarkan tabel 3, responden yang mengalami obesitas sentral sebanyak 15 orang (50\%) dengan kadar HbA1c meningkat dan sebanyak 15 orang (50\%) dengan kadar HbAlc normal, sedangkan responden yang tidak mengalami obesitas sentral seluruhnya (100\%) dengan kadar HbAlc normal.

Dilakukan uji normalitas data menggunakan uji Kolmogorov-Smirnov didapatkan nilai $\mathrm{p}$ untuk obesitas sentral $=0,222$ dan nilai $\mathrm{p}$ kadar $\mathrm{HbA} 1 \mathrm{c}=0,102$ yang berarti bahwa distribusi data normal sehingga analisis bivariat menggunakan uji korelasi Pearson Product Moment. Hasil analisis dengan uji korelasi Pearson Product Moment didapatkan nilai $\mathrm{p}=0,001(\mathrm{p}<0,05)$ yang menandakan bahwa terdapat hubungan yang bermakna antara obesitas sentral dengan kadar HbA1c. Didapatkan nilai Pearson Correlation $\mathrm{r}=0,456$ yang berarti kekuatan korelasi sedang dengan arah positif, sehingga disimpulkan terdapat hubungan bermakna antara obesitas sentral dengan kadar $\mathrm{HbAlc}$, dimana semakin tinggi ukuran lingkar pinggang semakin tinggi kadar HbA1c (Tabel 3).

\section{PEMBAHASAN}

Dalam penelitian ini didapatkan sebanyak 30 orang (60\%) mengalami obesitas sentral dan sebanyak 20 orang (40\%) tidak mengalami obesitas sentral, rerata ukuran diameter lingkar pinggang responden yang mengalami obesitas sentral sebesar $97,90 \mathrm{~cm}$ dengan nilai minimum $82 \mathrm{~cm}$ dan maksimum $105 \mathrm{~cm}$ sedangkan rerata ukuran diameter lingkar pinggang responden yang tidak mengalami obesitas sentral sebesar $81 \mathrm{~cm}$ dengan nilai minimum $76 \mathrm{~cm}$ dan maksimum $89 \mathrm{~cm}$. Hal ini sesuai kriteria IDF yang menyatakan bahwa obesitas sentral ditandai dengan lingkar pinggang untuk laki-laki adalah 
$\geq 90 \mathrm{~cm}$ sedangkan pada perempuan yang memiliki lingkar pinggang $\geq 80 \mathrm{~cm} .{ }^{11}$

Prevalensi obesitas sentral cenderung meningkat pada rentang usia 30-50 tahun. Sugianti (2009) dalam penelitian tentang Faktor Risiko Obesitas Sentral Pada Orang Dewasa di DKI Jakarta: Analisis Lanjut Data Riskesdas 2007 menunjukkan bahwa prevalensi obesitas sentral ditemukan lebih tinggi pada sampel usia 35-54 tahun karena pada usia yang lebih tua diketahui terjadi penurunan pada massa otot dan peningkatan pada massa jaringan lemak. ${ }^{12}$ Putri (2013) dalam penelitian tentang Hubungan Obesitas dengan Kadar HbAlc Pasien Diabetes Melitus Tipe 2 di Laboratorium Patologi Klinik Rumah Sakit Umum Daerah Abdul Moeloek Provinsi Lampung yang memperlihatkan bahwa mayoritas pasien DM tipe 2 di Laboratorium PK RSUD Abdul Moeloek berusia lebih dari 45 tahun. $^{2}$ Purwandari (2014) dalam penelitian tentang Hubungan Obesitas Dengan Kadar Gula Darah Pada Karyawan di RS Tingkat IV Madiun memperlihatkan bahwa mayoritas karyawan yang dijadikan sampel penelitian berusia 41-50 tahun. ${ }^{13}$

Pemeriksaan kadar HbAlc dilakukan dengan pengambilan sampel darah vena dan diperoleh data yaitu ada kadar HbAlc yang meningkat dan normal. Rerata kadar $\mathrm{HbA1c}$ responden yang meningkat sebesar $8,453 \%$ dengan nilai minimum $6,70 \%$ dan maksimum $8,90 \%$ sedangkan rerata kadar $\mathrm{HbAlc}$ responden yang normal sebesar $5,806 \%$ dengan nilai minimum $4,60 \%$ dan maksimum $6,40 \%$. Responden yang mengalami obesitas sentral dengan kadar HbAlc meningkat sebanyak 15 orang $(50 \%)$ dan kadar HbAlc normal sebanyak 15 orang (50\%), sedangkan responden yang tidak mengaalami obesitas sentral seluruhnya yaitu 20 orang (100\%) dengan kadar HbAlc normal.

Berdasarkan uji korelasi Pearson Product Moment untuk menganalisis hubungan antara obesitas sentral dengan kadar HbA1c didapatkan nilai $\mathrm{p}=0,001$ dan nilai Pearson Correlation $\mathrm{r}=$ 0,456 yang berarti terdapat hubungan positif yang bermakna antara obesitas sentral dengan kadar $\mathrm{HbA1c}$, dimana semakin tinggi ukuran lingkar pinggang semakin tinggi kadar HbAlc. Penelitian yang dilakukan oleh Martins, et al pada tahun 2012 yang mendapatkan hasil hubungan positif signifikan dengan kekuatan sedang $(\mathrm{p}<0,05$ dan $r=0,33$ ) antara lingkar pinggang dengan kadar $\mathrm{HbAlc}$ pada orang dewasa. Martins, et al menyimpulkan bahwa lingkar pinggang pada orang dewasa dengan obesitas sentral dapat digunakan sebagai prediktor kadar HbAlc pada orang dewasa. ${ }^{14}$

Penelitian lain yang dilakukan oleh Darmayanti (2014) tentang Korelasi Lingkar Pinggang dan
Rasio Lingkar Pinggang Panggul Terhadap HbA1c pada Karyawan Pria Dewasa Sehat di Universitas Sanata Dharma Yogyakarta menggunakan sampel orang dewasa usia 40-50 tahun sebanyak 66 orang. Hasil penelitian ini menunjukkan bahwa adanya korelasi positif bermakna antara lingkar pinggang dengan kadar HbAlc $(r=0,296 ; p=0,016)$ pada karyawan pria dewasa sehat usia 40-50 tahun di Universitas Sanata Dharma Yogyakarta. ${ }^{15}$ Devang $\mathrm{N}$, et al pada tahun 2016 yang mendapatkan hasil hubungan positif signifikan dengan kekuatan sedang ( $\mathrm{p}<0,05$ dan $r=0,360)$ antara lingkar pinggang dengan kadar HbAlc pada orang dewasa. Hasil tersebut dapat menyimpulkan bahwa lingkar pinggang pada orang dewasa dengan obesitas dapat digunakan sebagai prediktor kadar $\mathrm{HbAlc}$ pada orang dewasa, menandakan bahwa lingkar pinggang dapat menjadi indeks alternatif untuk penanda obesitas dan diasosiasikan dengan penyakit sindroma metabolik dan lemak viseral. ${ }^{16}$

Tchernof (2013) dalam penelitian tentang Pathophysiology of Human Viseral Obesity: An Update yang menyatakan bahwa obesitas merupakan salah satu faktor penyebab kenaikan kadar HbAlc di dalam darah. Obesitas dapat mengakibatkan gangguan pada proses uptake glukosa ke dalam sel sehingga mengakibatkan kadar glukosa di dalam darah meningkat. Suatu penelitian tentang pengujian $\mathrm{HbA1c}$ dapat membantu memprediksi kemungkinan terjadinya diabetes dimasa depan. HbA1c merupakan tes yang berguna untuk skrining diabetes secara periodik. Pada penelitian ini pasien dengan HbAlc yang normal memiliki risiko kejadian diabetes yang rendah namun pasien dengan $\mathrm{HbAlc}$ meningkat yang tidak memiliki riwayat diabetes mungkin perlu lebih berhati-hati untuk mengurangi risiko diabetes, terutama jika mengalami kelebihan berat badan atau obesitas. ${ }^{17}$ Sedangkan menurut Putri (2013), obesitas sentral yang diukur melalui lingkar pinggang diasosiasikan dengan peningkatan jumlah lemak tubuh yang dapat menimbulkan resistensi insulin yang merupakan salah satu faktor utama penyebab meningkatnya kadar glukosa darah. Pankreas bekerja lebih keras untuk meningkatkan sekresi insulin sehingga kadar glukosa darah masih dapat dipertahankan dalam kondisi normal pada fase awal terjadinya resistensi insulin. Saat sel-sel pankreas tidak mampu lagi mengkompensasi pada fase lanjut, maka sekresi insulin akan mengalami penurunan secara bertahap, sehingga barulah timbul hiperglikemia puasa. ${ }^{2}$

Penelitian sejenis juga pernah dilakukan oleh Evelyn tahun 2017 di Universitas Diponegoro. Hasil penelitian oleh Evelyn (2017) berbanding terbalik dengan penelitian ini. Hasil penelitian 
berdasarkan hasil uji analisis Spearman antara lingkar pinggang dan $\mathrm{HbAlc}$ didapatkan hasil $\mathrm{p}=$ 0,$327 ; \mathrm{r}=0,185$. Hal ini menunjukkan bahwa tidak didapatkan hubungan antara lingkar pinggang dan HbAlc. Perbedaan hasil penelitian ini disebabkan oleh usia responden dimana penelitian Evelyn menggunakan sampel mahasiswa berusia 18-24 tahun. Hal ini menunjukkan bahwa subyek masih dalam kategori usia produktif dimana resistensi insulin jarang terjadi pada usia tersebut. ${ }^{18}$ Menurut WHO dalam Kristanti (2016), usia lebih dari 25 tahun akan mengalami kenaikan glukosa darah sekitar $1-2 \mathrm{mg} / \mathrm{dl}$ per tahun dan glukosa darah setelah makan sekitar 5,6-13 mg/dl per tahun. Seiring dengan pertambahan usia terjadi penurunan fungsi dari pankreas yang mengakibatkan sensitivitas pankreas untuk bereaksi terhadap insulin menurun. Peningkatan usia dapat mempengaruhi fungsi dari pankreas dalam memproduksi insulin. Insulin yang bertindak untuk menjaga kadar gula darah berkurang jumlahnya sehingga kadar gula darah tidak dapat didistribusikan oleh tubuh untuk organ yang membutuhkan seperti otot. Hal ini terjadi karena jumlah dari insulin sebagai mediator penyalur gula darah ke otot berkurang jumlahnya. Akibat yang ditimbulkan dari kurangnya jumlah insulin yaitu peningkatan kadar gula darah. Mekanisme ini juga disebut sebagai insulin resistensi yang berarti bahwa sensitivitas insulin terhadap gula darah menurun. ${ }^{19}$

\section{SIMPULAN}

Terdapat hubungan positif yang bermakna antara obesitas sentral dengan kadar HbAlc pada penduduk usia 30 - 50 tahun di Lingkungan Batursari, Desa Bitera, Gianyar dengan nilai $\mathrm{p}=$ 0,001 dan nilai Pearson Correlation $r=0,456$. Hasil penelitian ini dapat digunakan sebagai data dasar bagi peneliti berikutnya serta dapat mengendalikan faktor-faktor yang dapat mempengaruhi obesitas sentral seperti gaya hidup seperti merokok dan aktivitas fisik.

\section{KONFLIK KEPENTINGAN}

Penulis menyatakan tidak terdapat suatu konflik kepentingan terhadap publikasi dari artikel ini.

\section{PENDANAAN}

Penelitian ini tidak mendapatkan suatu pendanaan yang diberikan oleh pemerintah ataupun lembaga swasta lainnya.

\section{KONTRIBUSI PENULIS}

Konsep penelitian: Putu Devita Sucitawati, DGD. Dharma Santhi, AA Ngurah Subawa. Pengumpulan data, input data dan pengolahan data: Putu Devita Sucitawati. Penyusunan naskah Penelitian: Putu Devita Sucitawati.

\section{ETHICAL CLEARANCE NUMBER}

\section{9/UN.14.2.2/KEP/2018}

\section{DAFTAR PUSTAKA}

1. PERKENI. Konsensus Pengelolaan dan Pencegahan Diabetes Mellitus tipe II di Indonesia. Jakarta: PERKENI. 2015.

2. Putri, Asticaliana. Hubungan Obesitas dengan Kadar HbAlc Pasien Diabetes Melitus Tipe 2 di Laboratorium Patologi Klinik Rumah Sakit Umum daerah Abdul Moeloek Provinsi Lampung. Medical Journal of Lampung University. 2013. 2(4), 9-11.

3. WHO. Obesity: preventing and managing the global epidemic. WHO Technical Report Series. 2004. 894 (1), 6-8.

4. Manungkalit, Maria. Hubungan Lingkar Pinggang dengan Faktor Risiko Diabetes Mellitus (Tekanan Darah, Kadar Gula Darah dan Indeks Massa Tubuh) Pada Usia Dewasa Awal. Jurnal Ners Lentera. 2015.3(1), 22-25.

5. Sari M., Wijaya D. Relationship between calorie intake, physical activity, and dopamine D2 receptor Taq1A gene polymorphism in normal-weight, overweight, and obese students of the faculty of medicine of university of Sumatera Utara.Bali Medical Journal. 2017. 6(1): 125-129. DOI: 10.15562/bmj.v6i1.394.

6. Yuhara, Novena. "Korelasi Lingkar Pinggang dan Rasio Lingkar Pinggang Panggul Terhadap HbAlc Pada Pria Dewasa Sehat di Desa Kepuharjo Kecamatan Cangkringan Sleman Yogyakarta”. Yogyakarta: Universitas Sanata Dharma. 2016.

7. Srinivasan. Association Between Waist Circumference and Serum Triacylglycerol Status in Type 2 Diabetes Mellitus. Journal of Clinical and Diagnostic Research. 2013. 7(4), 634.

8. Septyaningrum, Nenni. Lingkar Perut Mempunyai Hubungan Paling Kuat dengan Kadar Gula Darah. Jurnal Berkala Epidemiologi. 2014. 2(1), 48-51.

9. Kadir, Akmarawita. Penentu Kriteria Obesitas. Surabaya: Universitas Negeri Surabaya. 2015.

10. Setiawan, Meddy. Pre-Diabetes dan Peran HbAlc Dalam Skrinning dan Diagnosis Awal Diabetes Mellitus. Universitas Muhammadiyah Malang. 2011. 7(1), 59-61.

11. Consensus statements [Internet]. IDF.org. 2019 [cited 4 March 2019]. Available from:https://www.idf.org/e-library/ consensus-statements/60-idfconsensus-worldwidedefinitionof-the-metabolic-syndrome

12. Sugianti E. Faktor Risiko Obesitas Sentral Pada Orang Dewasa di DKI Jakarta: Analisis Lanjut Data Riskesdas 2007. Gizi Indonesia. 2009;32(2):109.

13. Purwandari, Henny. Hubungan Obesitas dengan Kadar Gula Darah Pada Karyawan di RS Tingkat IV Madiun. Jurnal Efektor. 2014. 25(1), 66.

14. Martins RA, Jones JG, Cumming SP, Coelho e Silva MJ, Teixeira AM, Veríssimo MT. Glycated Hemoglobin and Associated Risk Factors in Older Adults. Cardiovasc Diabeto. 2012. 11(1):13

15. Darmayanti D. Korelasi Lingkar Pinggang dan Rasio Lingkar Pinggang Panggul terhadap HbAlc pada Karyawan Pria Dewasa Sehat di Universitas Sanata Dharma. Universitas Sanata Dharma Yogyakarta. 2014. 39-43. 
16. Devang N, Nandini M, Rao S, Adhikari P. Mid Arm Circumference: An Alternate Anthropometric Index of Obesity in Type 2 Diabetes and Metabolic Syndrome. Br J Med Res. 2016. 12(1):1-8.

17. Tchernof, Andre. Pathophysiology of Human Viseral Obesity: An Update. Physiol Rev. 2013. 1(1), 359-380.

18. Evelyn M. Hubungan Lingkar Pinggang Dan Lingkar Lengan Atas Dengan HbAlc Pada Obesitas: Studi Kasus Pada Mahasiswa Fakultas Kedokteran Universitas Diponegoro. Jurnal Kedokteran Diponegoro. 2017. 7(2): 1279.
19. Kristanti EE. Karakteristik Prediabetes Di Puskesmas Pesantren I Kota Kediri. J Jurnal Biokimia. 2016. 2(2):156-64.

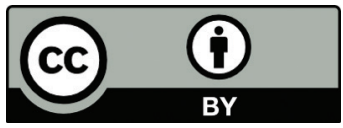

This work is licensed under a Creative Commons Attribution 